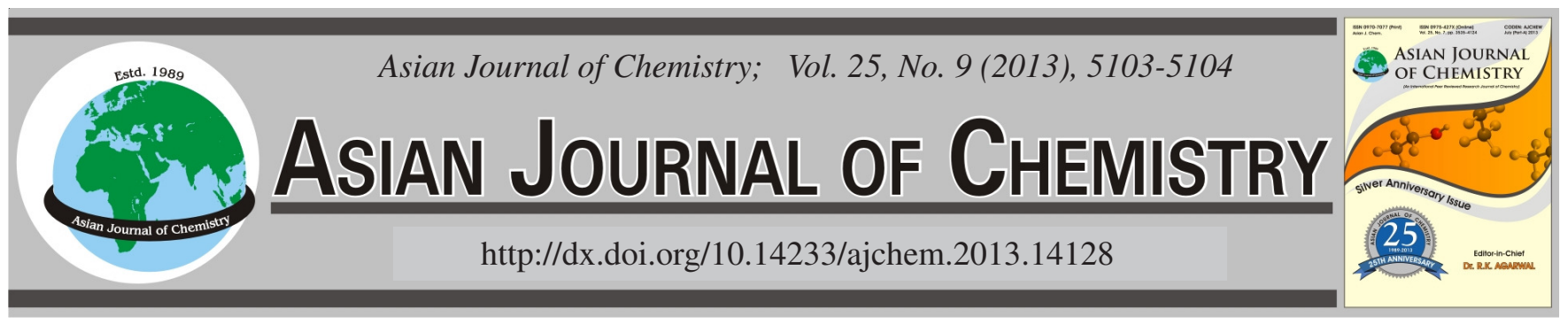

NOTE

\title{
Determination of Trace Elements Content in Mineral Water and its Processed Mineral Water by ICP-MS
}

\author{
Yukui Rui , Yanbei Zhang and ShengLiang Li
}

College of Resources and Environmental Sciences, China Agricultural University, Beijing 100193, P.R. China

*Corresponding author: Tel: +8610 62732574; E-mail: ruiyukui@163.com

\begin{abstract}
Good natural mineral water has become important strategic resource. The macro and trace elements and five heavy metals were determined in natural mineral water from Emei mountain of Beijing and its processed mineral water by ICP-MS. The results showed that (1) natural mineral water contained many macro elements, especially $\mathrm{Ca}, \mathrm{Mg}, \mathrm{Si} \mathrm{Na}$ and $\mathrm{K}$, and the processing course did not significantly reduce the concentration of these elements; (2) natural mineral water contained much trace elements, including $\mathrm{Li}, \mathrm{Zn}, \mathrm{Sr}, \mathrm{Se}, \mathrm{Mn}, \mathrm{Cu}$ and $\mathrm{Fe}$, especially Sr, Fe and Se, and after processing, many trace elements increased significantly, such as Zn, Li and Se; (3) the natural mineral water from Emei mountain of Beijing and its processed mineral water contain much little heavy metals. By contrast with the national standards, the natural mineral water from Emei mountain of Beijing is excellent mineral water and its processed mineral water also meet the national hygiene standards of drinking water.

Key Words: Trace elements, Heavy metals, Mineral water, ICP-MS.
\end{abstract}

- - - - - - - - - - - - - - - - - - - - - - - - - -

Water is the most important nutrition for human health, but with the development of society more and more waters are polluted and less and less water is potable $\mathrm{e}^{1,2}$. The pollutants include organic pollutants ${ }^{3}$ and inorganic pollutants, such as heavy metals ${ }^{4}$. On the another hand, we drink not only for $\mathrm{H}_{2} \mathrm{O}$ but also trace elements, including $\mathrm{K}, \mathrm{Ca}, \mathrm{Mg}, \mathrm{Sr}, \mathrm{Si}$ and many other elements.

For water safety and water nutrition, there are many mineral water brands, most which named high trace elements content and safety. But natural mineral water must meet the national standards and must be processed before sale as drinking water and the processing course can also be the pollution pathway.

This paper determined the contents of trace elements and heave metals in a spring from Beijing and its processed mineral water to study the nutrition and safety of this mineral water and its processed mineral water.

The natural mineral water was collected from Emei mountain of Pinggu district, Beijing city. Processed mineral water: the natural mineral water was collected from Emei mountain was filtered through quartz sand and almond carbon firstly, then filtered through carbon fiber and finally sterilized by ozone.

\section{Method}

Parameters of apparatus: Parameters of inductively coupled plasma: Referred to Huang et al. ${ }^{5}$ method: power, 1200
$\mathrm{W}$; rate of flow of cooling gas $(\mathrm{Ar}), 15.0 \mathrm{~L} / \mathrm{min}$; rate of flow of supplemental gas $(\mathrm{Ar}), 1.80 \mathrm{~L} / \mathrm{min}$; rate of flow of carried gas (Ar), $0.90 \mathrm{~L} / \mathrm{min}$. Parameters of mass spectrometry: vaccum of analysis room, $5.90 \times 10^{-6}$ Tor $\mathrm{r}$; impulse voltage, 1100 V. Parameters of detecting: resolution (10\% peak height): $0.8 \mathrm{amu}$ (Nor), $0.6 \mathrm{amu}(\mathrm{H})$; retention period, $100 \mathrm{~ms}$, times of replication, 5; times of circulation, 8; mode of analysis, scanning of mass, period of analysis, $72 \mathrm{~s}$; rate of sample, 1 $\mathrm{mL} / \mathrm{min}$.

Macronutrient: K, Na, Ca, Mg, Si are essential for human health and play an important role on metabolism of human body. For example, potassium is widely distributed in the muscles, nerves and blood potassium and closely relative to activity of skeletal muscle and nerve conduction, which plays a significant role in the prevention of severe hypertension, stroke, muscular dystrophy, heart disease, rickets and even cancer ${ }^{6}$.

The results (Table-1) showed that natural mineral water contained many macro elements, especially $\mathrm{Ca}, \mathrm{Mg}, \mathrm{Si} \mathrm{Na}$ and $\mathrm{K}$ and the processing course did not significantly reduce the concentration of these elements.

Micro-and beneficial elements: The results showed that natural mineral water contained much trace elements, including $\mathrm{Li}, \mathrm{Zn}, \mathrm{Sr}, \mathrm{Se}, \mathrm{Mn}, \mathrm{Cu}$ and $\mathrm{Fe}$, especially $\mathrm{Sr}, \mathrm{Fe}$ and $\mathrm{Se}$ which are all the essential elements for human health, so we can 


\begin{tabular}{ccc}
\hline \multicolumn{3}{c}{ TABLE-1 } \\
\multicolumn{3}{c}{ CONCENTRATIONS OF MACRONUTRIENT IN NATURAL } \\
MINERAL WATER AND PROCESSED MINERAL WATER
\end{tabular}

\begin{tabular}{ccc} 
TABLE-2 \\
CONCENTRATIONS OF MICRO-AND BENEFICIAL \\
\multicolumn{3}{c}{ ELEMENTS IN NATURAL MINERAL WATER AND } \\
PROCESSED MINERAL WATER
\end{tabular}

supplement trace elements by drinking mineral elements. After processing, many trace elements increased significantly, such as $\mathrm{Zn}, \mathrm{Li}$ and Se; and $\mathrm{Mn}$ and Fe decreased significantly. All these elements in natural mineral water and processed mineral water meet the national hygiene standards of drinking water ${ }^{7}$ (Table-2).

Heavy metals: Today people increasingly focused on the safety of drinking water, especially heavy metals $\mathrm{As}, \mathrm{Pb}, \mathrm{Cd}$, $\mathrm{Cr}$ and $\mathrm{Hg}$ which are harmful to human health. The results (Table-3) showed that natural mineral water contained little heavy metals and concentrations of heavy metals had no significant changes after processing. All heavy metals in natural mineral water and processed mineral water meet the national hygiene standards of drinking water ${ }^{7}$.

\begin{tabular}{ccc}
\multicolumn{4}{c}{ TABLE-3 } \\
\multicolumn{3}{c}{ CONCENTRATIONS OF FIVE KINDS OF } \\
\multicolumn{3}{c}{ HEAVY METALS IN NATURAL MINERAL } \\
WATER AND PROCESSED MINERAL WATER \\
\hline \multirow{2}{*}{ Elements } & $\begin{array}{c}\text { Natural mineral } \\
\text { water }(\mathrm{ng} / \mathrm{mL})\end{array}$ & $\begin{array}{c}\text { Processed mineral } \\
\text { water }(\mathrm{ng} / \mathrm{mL})\end{array}$ \\
& $0.54 \mathrm{a}$ & $0.33 \mathrm{a}$ \\
$\mathrm{As}$ & $0.002 \mathrm{a}$ & $0.007 \mathrm{a}$ \\
$\mathrm{Hg}$ & $0.02 \mathrm{a}$ & $0.03 \mathrm{a}$ \\
$\mathrm{Pb}$ & $0.82 \mathrm{a}$ & $0.84 \mathrm{a}$ \\
$\mathrm{Cr}$ & $0.003 \mathrm{a}$ & $0.004 \mathrm{a}$ \\
$\mathrm{Cd}$ & & \\
\hline
\end{tabular}

\section{Conclusion}

By contrast with the national standards, the natural mineral water from Emei mountain of Beijing is excellent mineral water and its processed mineral water also meet the national hygiene standards of drinking water. The natural mineral water from Emei mountain of Beijing and its processed mineral water contain many kinds of trace and beneficial elements. The natural mineral water from Emei mountain of Beijing and its processed mineral water contain much little heavy metals.

\section{ACKNOWLEDGEMENTS}

This work was funded by the National Science Foundation of China (No. 41130526). The authors thank Ms. Wang Xiaoyan (School of Public Health, Peiking University, China) for help.

\section{REFERENCES}

1. H. Fan and X.-B. Qi, J. Irrig. Drainage, 31, 117 (2012).

2. L.-P. He, X. Zhang and S. Chen, Environ. Sci. Survey, 31, 24 (2012).

3. C.H. Wei, X.X. Zhang, Y. Ren, Y. Hu and H.Z. Wu, Environ. Chem., 30, 300 (2011).

4. Y. Ji, J. Zhang, Q. Chen and H.-B. Fan, Jiangxi Sci., 28, 714 (2010).

5. Z.Y. Huang, Q. Zhang, K. hu, J.L. Wu and P.Y. Yang, Spectrosc. Spect. Anal., 23, 962 (2003)

6. M.-J. Wu, Studies Trace Elem. Health, 28, 61 (2011).

7. National Standards of China, Drinking Natural Mineral Water, No. GB, p. 8537 (1995). 